\title{
Does Diabetes Alter Immunolocalization of Galectin-1 and Galectin-3 in the Rat Ovary?
}

\author{
¿La Diabetes Altera la Inmunolocalización de Galectina-1 y Galectina-3 en el Ovario de Rata?
}

\author{
Berna Özdenoglu* \& Serpil Ünver Saraydin*
}

ÖZDENOGLU, B. \& SARAYDIN, S. U. Does diabetes alter immunolocalization of galectin-1 and galectin-3 in the rat ovary? Int. J. Morphol., 34(2):742-751, 2016.

SUMMARY: Diabetes mellitus (DM), is a metabolic disease occurring via insulin secretion deficiency from the pancreas and/or an insufficiency of tissue response to insulin. The present study is intended to show of immunolocalizations of beta-galactose-binding proteins Galectin-1 and Galectin-3 in diabetic rat ovarium and their relationship with diabetes. In this study, 8 to 10-week-old, 250-300 $\mathrm{g}$ weighing 50 mature female rats were used, in order to establish diabetes mellitus in those animals, $60 \mathrm{mg} / \mathrm{kg}$ intravenous streptozotocin was injected to each animal. After death, diabetics and non-diabetics rats's routine tissue processing steps is done to rat ovarial tissues for immunohistochemical investigation. Strong expressions of Galectin-1 and Galectin-3 were observed in the ovarial germinal epithelium and vascular endothelial. While the strong intense expression of Galectin-1 was seen in the zona pellucida, Galectin-3 expression was strongest in the cytoplesmic regions of cells. Zona pellucida has 3 protein complexes (ZP1, ZP2 and ZP3) in rats and in humans and they have the capability of recognizing the carbonhydrate fields in tissues. The strong expression of galectins in those regions could be the result of carbonhydrate binding properties expression of Gal-3 in the cytoplasmic regions of growing follicles could suggest the idea that Gal-3 could have effects on follicle growth. In conclusion, beta galactose-binding proteins Gal-1 and Gal-3 had stronger immunolocalization in diabetic rat ovarium when compared to the controls. Diabetes could increase the Gal-1 and Gal-3 expressions in the ovarial tissue.

KEY WORDS: Galectin-1; Galectin-3; Ovary; Diabetes; Rat.

\section{INTRODUCTION}

Development of follicles in the ovaries that have an indispensable role in fulfilling the reproductive function in mammals, on the one hand, produces the ovum capable of being fertilized, and on the other hand, ensures that simultaneous changes and developments occur in some regions of the reproductive system (Akkoyunlu et al., 2000). Ovary is a dynamic organ that undergoes morphological and biochemical changes with the impact of contributing factors, as well as of different hormones, at each cycle (Balla et al., 2003). Diabetes is a chronic and metabolic disease characterized by hyperglycemia and hypoglycemia, which affect a large proportion of the world's population. It occurs due to either the pancreas' failure to secrete enough insulin or tissues' failure to respond to insulin properly, and influences protein, fat and carbohydrate metabolism (Saglam, 2004). Streptozotocin (STZ), a toxic glucose analogue that is specific to pancreatic beta cells, is one of the most preferred toxins to chemically induce the experimental diabetes and have long been used for the induction of diabetes in experimental animals (Kurçer \& Karaoglu, 2012). Galectin-1 is a homodimeric lectin with the specificity of b-galactosidase that belongs to galectin family of carbohydrate-binding proteins (Kaltner et al., 1997). As can also be localized in the nucleus membrane, cytoplasm and cell surface, Gal-1 protein has been reported to be involved in cell-cell, cell-substrate and cell-extracellular matrix interactions and in adhesion, apoptosis, cell cycle regulation, cell growth and migration and in neoplastic transformation, inflammation and tumor metastasis (Seyrek et al., 2001). Galectin-3 is one of the b-galactoside binding proteins (Krzeslak \& Lipinska, 2004). Galectin-3 is mostly found in the epithelial and immune cells. It is also expressed in the cytoplasm, cell surface and extracellular space (Volante et al., 2004). Galectin-3 can be localized in cell surface and nucleus (Gong et al., 1999). In our study, ovary tissues were harvested from streptozotocin-induced diabetic rats. The antibodies of galectin-1 and galectin-3 were applied to ovarian tissues for their expression. Then, their relationships with diabetes were evaluated. Thus, our study has determined whether there is any effect of diabetes on the localization of galectin- 1 and galectin-3. To the best of our knowledge, this study is the first report that investigates the localization of galectin-1 and galectin-3 in diabetic rat ovary. 


\section{MATERIAL AND METHOD}

The animals used in the study were raised under standard lighting conditions, namely 12/12 h light/dark, at room temperature. Rats were divided into control $(n=25)$ and diabetic $(n=25)$ groups. Thirty days after intramuscular administration $(60 \mathrm{mg} / \mathrm{kg}$ bodyweight) of streptozotocin (STZ; Sigma Chemical Co., St. Louis Missouri, USA) to animals to induce diabetes, diabetic and non-diabetic rats were anaesthetized with sodium pentobarbital $200 \mathrm{mg} / \mathrm{kg}$ intraperitoneally. Ovarian tissues taken after euthanasia were passed through routine processing protocols for light microscopy and immunohistochemical examinations. Hematoxylin-eosin was employed in order to demonstrate the overall morphology of the paraffin-embedded samples for light microscopic examination. Immunohistochemical techniques were applied to the tissue sections to show the localization of Galectin-1 and Galectin-3 molecules. A semiquantitative scoring method was used to evaluate the intensity of Galectin- 1 and Galectin-3 expressions in ovarian tissues of control and experimental groups. Evaluation results are presented in tables. All sections were examined by two independent observers. Based on staining intensities of Gal1 and Gal-3 antibodies in ovarian tissue sections, staining results were graded as negative (-), weak (+), moderate (++) and intense $(+++)$ (Vaskivuo et al., 2002).

\section{RESULTS}

Semi-quantitative scoring method was employed to evaluate Gal-1 and Gal-3 immunolocalization in many parts of diabetic rat ovary, such as epithelium, tunica albuginea, cortex, cortical blood vessels, medulla, fibroblast-like cells, primordial follicles, primordial follicle cells, primary oocytes, primary follicle, primary follicle cells, zona pellucida, theca interna, theca externa, secondary follicles, granulosa cells, antrum, corona radiata and culumus (Tables

Table I. Galectin-1 and Galectin-3 expression in the control group.

\begin{tabular}{|c|c|c|c|}
\hline Control Group & & Galectin-1 & Galectin-3 \\
\hline Epithelial & & + & ++ \\
\hline & Tunica Albuginea & ++ & ++ \\
\hline Corteks & & + & ++ \\
\hline & Corteks Blood Vessel & +++ & +++ \\
\hline Medulla & & ++ & +++ \\
\hline & Fibroblast-Like Cells & + & + \\
\hline & Medulla Blood Vessel & +++ & +++ \\
\hline Primordial Follicles & Primordial Follicle Cells & - & - \\
\hline & Primary Oocytes & - & - \\
\hline Primary Follicles & Primary Follicular Cells & + & + \\
\hline & Primary Oocytes & - & - \\
\hline & Zona Pellucida & ++ & - \\
\hline & Theca_nterna & - & + \\
\hline & Theca Eksterna & - & + \\
\hline Sekondary Follicles & Primary Oocytes & - & - \\
\hline & Zona Pellucida & +++ & + \\
\hline & Granuloza Cells & + & + \\
\hline & Antrum & +++ & + \\
\hline & Theca_nterna & - & + \\
\hline & Theca Eksterna & - & + \\
\hline Tertiary Follicles & Sekondary Oocyte & - & - \\
\hline & Zona Pellucida & + & ++ \\
\hline & Granuloza Cells & + & + \\
\hline & Antrum & +++ & +++ \\
\hline & Corona Radiata & + & - \\
\hline & Cumulus Oophorus & + & - \\
\hline & Theca_nterna & - & ++ \\
\hline & Theca Eksterna & - & - \\
\hline Corpus Luteum & Corpus Luteum Blood Vessel & ++ & +++ \\
\hline & Theca Lutein Cells & + & + \\
\hline & Granüloza Lutein Cells & + & + \\
\hline
\end{tabular}


Table II. Galectin-1 and Galectin-3 In the diabetic experimental group expression.

\begin{tabular}{|c|c|c|c|}
\hline Experimental Group & & Galectin-1 & Galektin-3 \\
\hline \multirow[t]{2}{*}{ Epithelial } & & - & +++ \\
\hline & Tunica Albuginea & - & +++ \\
\hline \multirow[t]{2}{*}{ Corteks } & & - & +++ \\
\hline & Corteks Blood Vessel & - & +++ \\
\hline \multirow[t]{3}{*}{ Medulla } & & ++ & +++ \\
\hline & Fibroblast-Like Cells & + & ++ \\
\hline & Medulla Blood Vessel & +++ & +++ \\
\hline \multirow[t]{2}{*}{ Primordial Follicles } & Primordial Follicle Cells & - & - \\
\hline & Primary Oocytes & - & - \\
\hline \multirow[t]{5}{*}{ Primary Follicles } & Primary Follicular Cells & + & - \\
\hline & Primary Oocytes & - & - \\
\hline & Zona Pellucida & ++ & ++ \\
\hline & Theca_nterna & - & - \\
\hline & Theca Eksterna & - & - \\
\hline \multirow[t]{6}{*}{ Sekondary Follicles } & Primary Oocytes & - & - \\
\hline & Zona Pellucida & +++ & ++ \\
\hline & Granuloza Cells & + & + \\
\hline & Antrum & +++ & ++ \\
\hline & Theca_nterna & - & + \\
\hline & Theca Eksterna & - & + \\
\hline \multirow[t]{8}{*}{ Tertiary Follicles } & Sekondary Oocyte & - & - \\
\hline & Zona Pellucida & - & +++ \\
\hline & Granuloza Cells & - & + \\
\hline & Antrum & +++ & +++ \\
\hline & Corona Radiata & - & + \\
\hline & Cumulus Oophorus & - & + \\
\hline & Theca_nterna & - & + \\
\hline & Theca Eksterna & - & - \\
\hline \multirow[t]{3}{*}{ Corpus Luteum } & Corpus Luteum Blood Vessel & ++ & +++ \\
\hline & Theca Lutein Cells & + & ++ \\
\hline & Granüloza Lutein Cells & + & ++ \\
\hline
\end{tabular}

I and II). It was observed that in the control group, Galectin1 expression was weak staining in germinal epithelium and moderate staining in basement membrane and tunica albuginea layer (Fig. 1A). While Gal-1 localization did not note in primordial follicles, it was weak staining in the primary follicles (Figs. 1B and 1C). Gal-1 expression was shown to be moderate in secondary- and tertiary follicles (Figs. 1D and 1E). In the experimental group, Gal-1 expression was observed to be intense in germinal epithelium, basement membrane and tunica albuginea (Fig. 1F). As Gal-1 localization did not discern in the primordial follicles, it noticed to be weak in the primary follicles (Figs. 2A and 2B). Gal-1 localization was observed to be moderate in secondary- and tertiary follicles (Figs. 2C and 2D). Gal-1 expression was noticed to be intense in medulla of both control and experimental groups (Figs. 2E and 2F).
Galectin-3 expression was observed to be weak in the germinal epithelium and intense in basement membrane and tunica albuginea layer in the control group (Fig. 3). While Gal-3 localization did not observed in the primordial follicle, it was weak staining in the primary follicle (Fig. 4). Gal-3 expression was demonstrated to be moderate in secondary- and tertiary follicles (Fig. 5). In the experimental group, Gal-3 expression was noted to be intense in germinal epithelium, basement membrane and tunica albuginea (Fig. 6). Whereas Gal-3 localization did not discern in the primordial follicle, it noticed to be weak expression in the primary follicles (Fig. 7). Gal-3 expression was observed to be moderate in secondary- and tertiary follicles (Fig. 8). Gal-3 expression was noticed to be intense in medulla of both control and experimental groups (Fig. 9). 


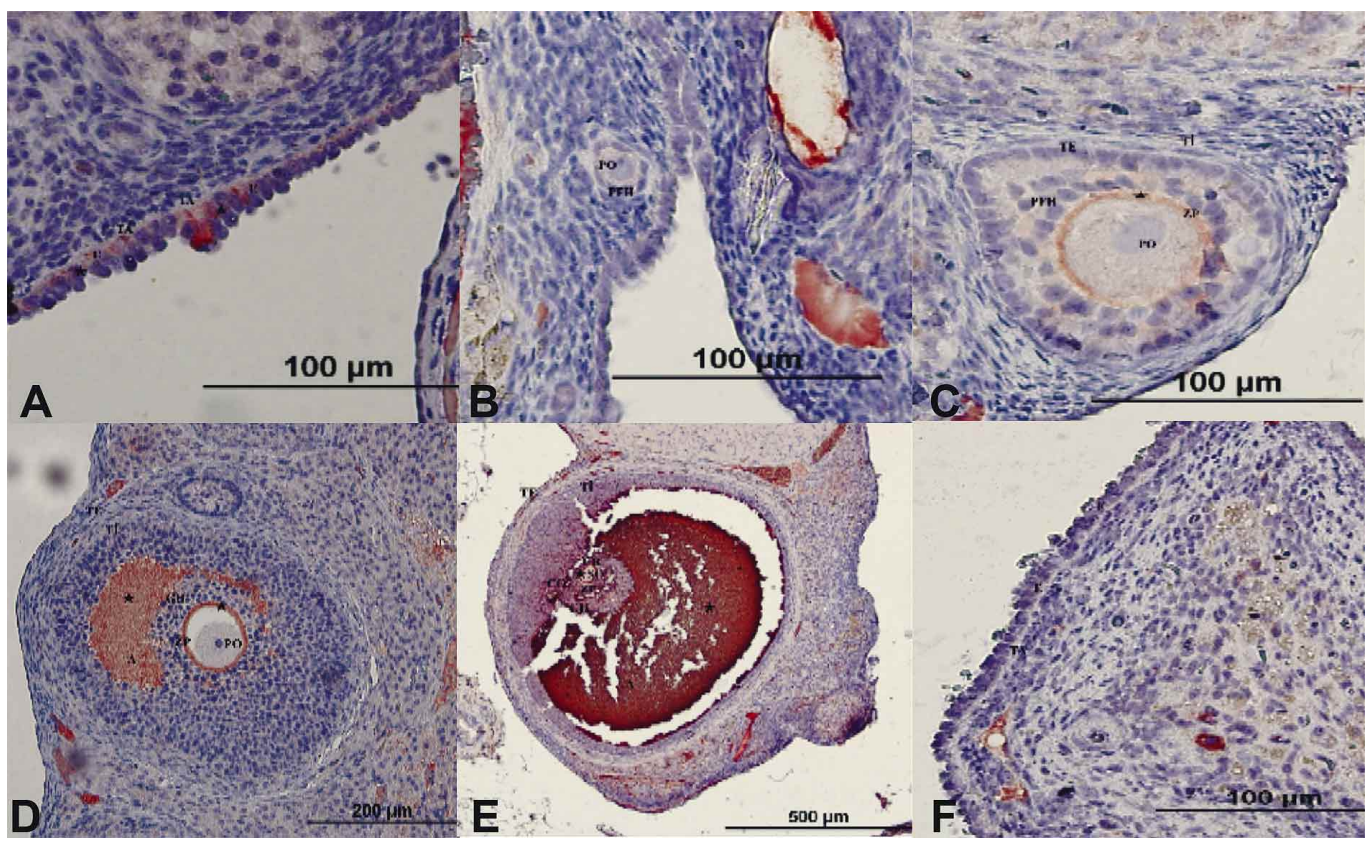

Fig. 1. A) Gal-1 immunulocalization of epithelial layer in control group (*). B) Gal-1 immunulocalization of primordial follicles in control group (*). C) Gal-1 immunulocalization of primary follicles in control group (*). D) Gal-1 immunulocalization of secondary follicles in control group (*). E) Gal-1 immunulocalization of tertiary follicles in control group (*). F) Gal-1 negative immunolocalization of epithelium in experimental group. Legends: Primary oocytes (PO), primordial follicles cells (PFH), Epithelial cells (E), tunica albuginea (TA), theca interna (TI), theca eksterna (TE), zona pellucida (ZP), antrum (A), granuloza cells (GH), Secondary oocytes (PO), corona radiata $(\mathrm{CR})$, cumulus oophorus $(\mathrm{CO})$.

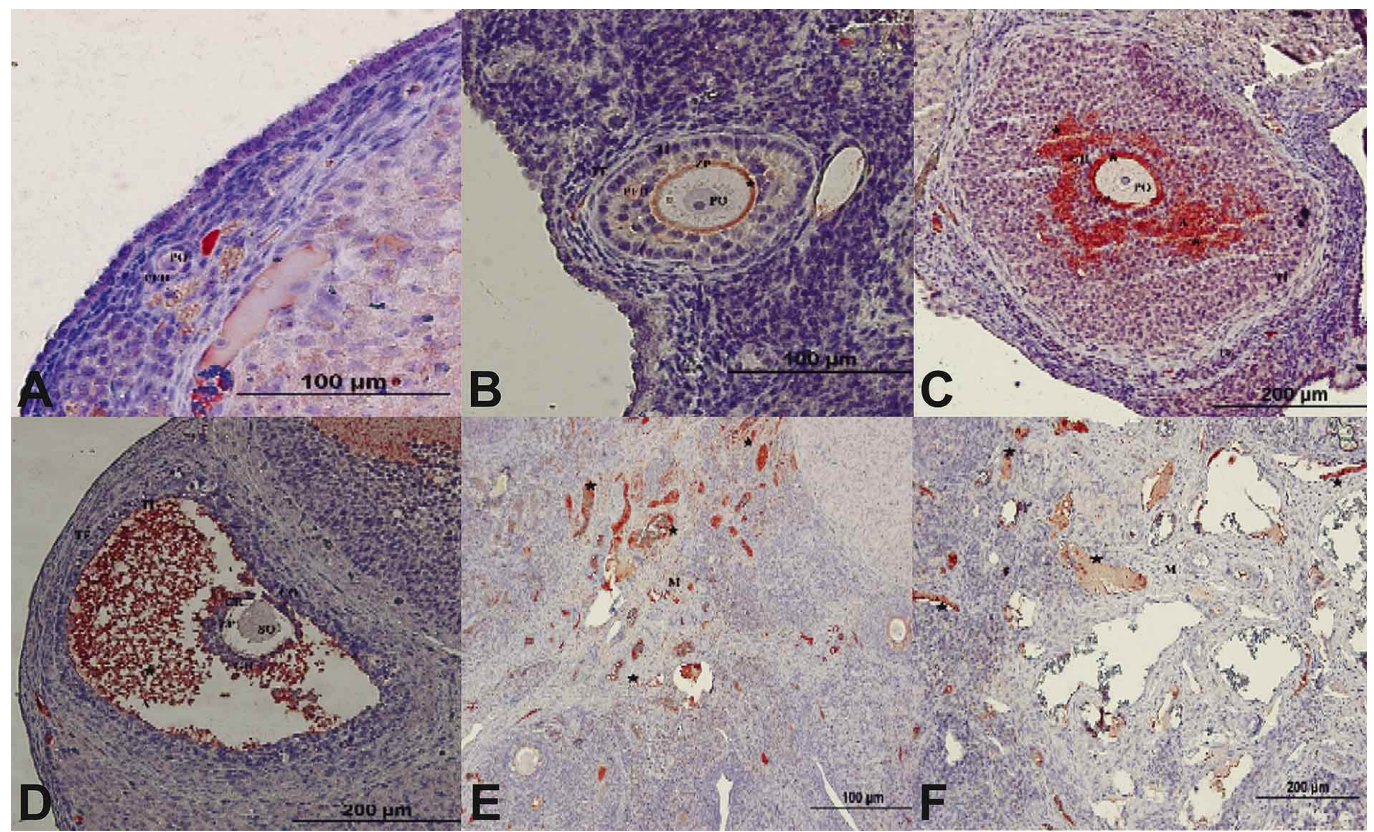

Fig. 2. A) Gal-1 negative immünolocalization of primordial follicles in experimental group. B) Gal-1 immunulocalization of primary follicles in experimental group (*). C) Gal-1 immunulocalization of secondary follicles in experimental group (*). D) Gal-1 immunulocalization of tertiary follicles in control group (*). E) Gal-1 immunulocalization of medulla in control group (*). F) Gal-1 immunulocalization of medulla in experimental group (*). Legends: Primary oocytes (PO), primordial follicle cells (PFH), zona pellucida (ZP), theca interna (TI), theca eksterna (TE), antrum (A), granuloza cells (GH), Secondary oocytes (PO), corona radiata (CR), cumulus oophorus (CO), Medulla (M). 


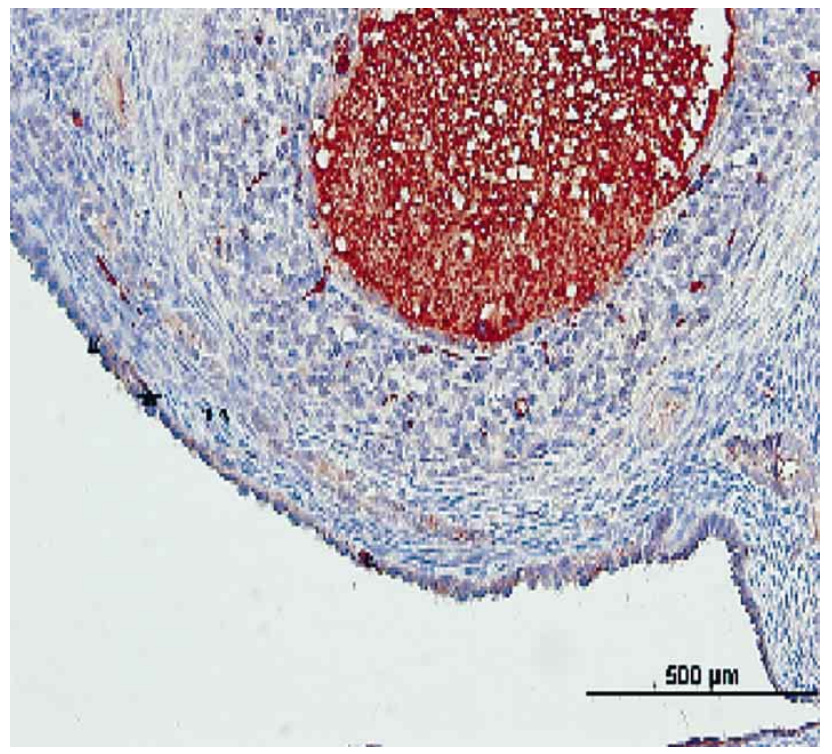

Fig. 3. Gal-3 immunulocalization of epithelial layer in control group (*). Legends: Epithelial cells $(\mathrm{EH})$, tunica albuginea (TA).

Fig. 4. A) Gal-3 negative immunulocalization of primordial follicles in control group (*). B) Gal-3 immunulocalization of primary follicles in control group (*). Legends: Primary oocytes (PO), primordial follicles cells (PFH), zona pellucida; (ZP), theca interna; (TI), theca eksterna (TE).

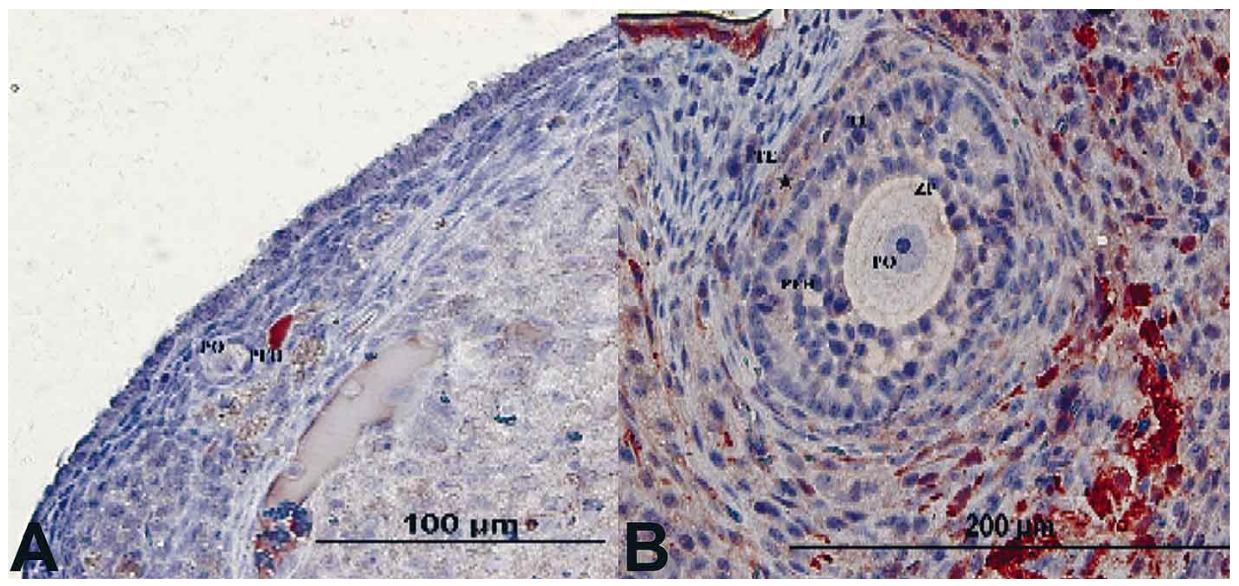

Fig. 5. A) Gal-3 immunulocalization of secondary follicles in control group (*). B) Gal3 immunulocalization of tertiary follicles in control group (*). Legends: Primary oocytes (PO), zona pellucida (ZP), antrum (A), theca interna (TI), theca eksterna (TE), granuloza cells $(\mathrm{GH})$, corona radiata (CR), cumulus oophorus (CO). 


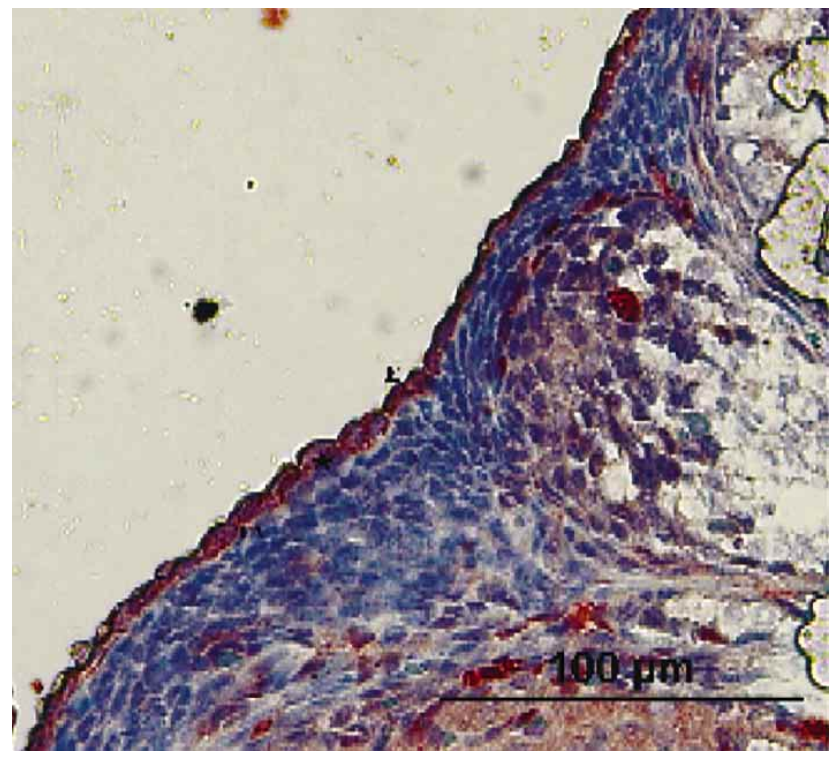

Fig. 6. Gal-3 immünolocalization of epithelium in experimental group. Legends: Epithelial cells (EH), tunica albuginea (TA).

Fig. 7. A) Gal-3 negative immünolocalization of primordial follicles in experimental group. B) Gal-3 immunulocalization of primary follicles in experimental group $(*)$. Legends: Primary oocytes (PO), primordial follicle cells (PFH), zona pellucida (ZP), theca interna (TI), theca eksterna (TE).
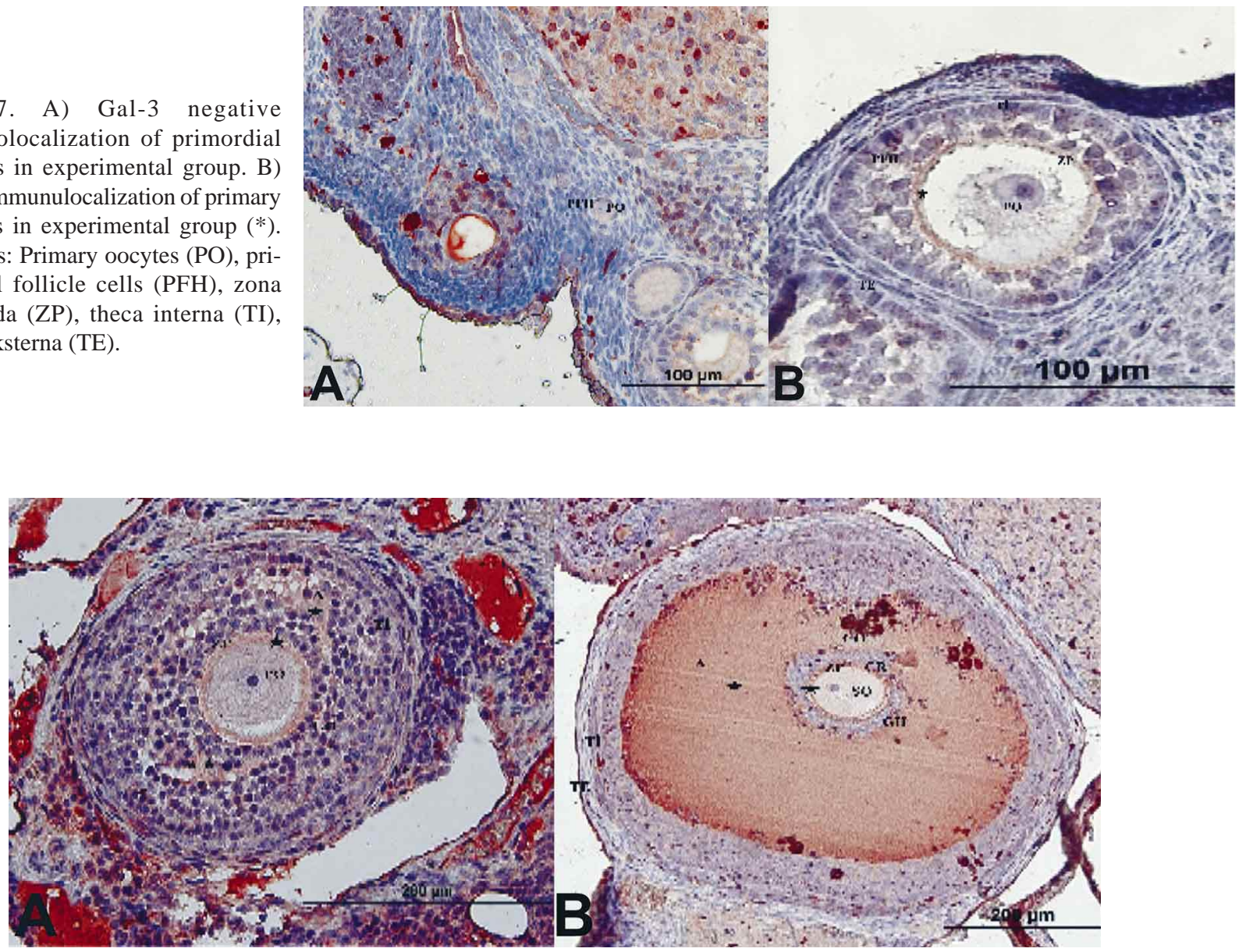

Fig. 8. A) Gal-3 immunulocalization of secondary follicles in experimental group (*). B) Gal-3 immunulocalization of tertiary follicles in control group (*). Legends: Primary oocytes (PO), zona pellucida (ZP), antrum (A), theca interna (TI), theca eksterna (TE), granuloza cells (GH), Secondary oocytes (PO), corona radiata (CR), cumulus oophorus (CO). 


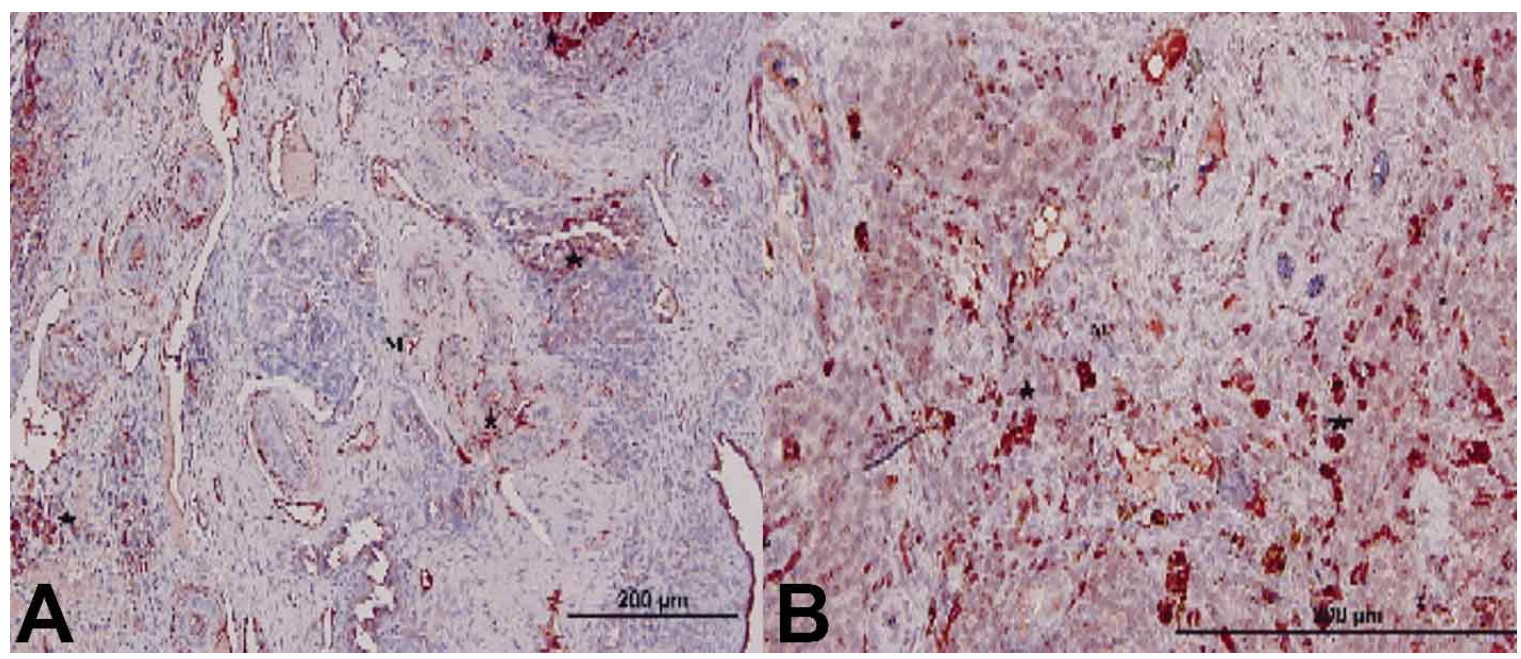

Fig. 9. A) Gal-3 immunulocalization of medulla in control group (*). B) Gal-3 immunulocalization of medulla in experimental group (*). Legends: Medulla (M).

\section{DISCUSSION}

Diabetes mellitus is a disease that consists of a heterogeneous group of metabolic disorders characterized by disturbances, which take place in carbohydrate, fat and protein metabolism as a result of defects in insulin secretion and/or insulin action or in both cases. If elevated blood sugar (hyperglycemia), the common outcome of the disease, cannot be kept under control, it can produce microvascular troubles such as retinopathy, nephropathy, peripheral and autonomic neuropathy, which are considered as chronic complications of diabetes, over time. For this reason, DM can shorten their life expectancy, as can be reduced quality of life of patients (Diabetes mellitus, 1985). Galectin, an animal lectin that recognizes $\beta$-galactosides of glycoconjugates, is involved in many biological functions such as cell growth, differentiation, apoptosis, and signal transduction. Gal-1 was intensely expressed in the ovarian stroma, including the interstitial glands and theca interna, and in the corpus luteum. Gal-3 is also localized in the corpus luteum. Galectin- 1 and -3 were expressed in the mouse ovary. In addition, galectin1 and -3 may mediate progesterone production and metabolism in luteal cells via different mechanisms (NioKobayashi \& Iwanaga, 2010). In our present study, ovarian tissues were removed from rats to be examined after inducing an experimental diabetes in animals. Then, Galectin- 1 and 3 localizations were investigated in ovarian tissues. In the first immunohistochemical report by Kwak et al. (2003) they are elucidated the expressional changes of gangliosides as cell surface receptor, GM3 expression in early embryonic stage of development and the effects of a high glucose concentration on oocyte fertilization in diabetic mouse ovaries during estrous cycle. GM3 with a simple carbohydrate structure is known to be involved in the induction of cell differentiation, modulation of cellular proliferation, signal transduction, and maintenance of fibroblast morphology. It is likely that GM3 may be present in granulosa cells of primary follicles. In such a case, an immunohistochemical significant change in GM3 expression during follicular development may support the hypothesis that this ganglioside plays an essential role in follicular growth and ovulation (Kwak et al.). Hormonal stimulation may influence GM3 expression since ovulation is regulated by many hormones, such as FSH, luteinizing hormone (LH), prolactin and estrogen (Erickson, 1978). Other studies have shown that FSH and insulin together raise the production of GM3 by immature granulosa cells (Hattori \& Horiuchi, 1992), but that FSH alone can be less effective than expected. Based on these suggestions, it can be said that a complex mechanism is involved in GM3 expression during follicular development (Erickson). The results obtained in diabetic mice indicate that a high ambient glucose level may have an effect upon GM3 expression during development. Considering where Gal-1 and Gal-3 are localized, it can be concluded that diabetes have an impact on the Gal-1 and -3 expression, that galectin- 1 and -3 may play a fundamental role in follicular growth and ovulation, and that a complicated mechanism is implicated in Gal-1 and -3 expression. Eriksson et al. (1998) stated that sorbitol levels elevate in rat embryos exposed to high levels of glucose and these 
embryos display impaired growth and substantially higher rates of congenital malformations. It can be inferred from available evidence that the metabolites generated in the metabolism of glucose may be harmful to embryo during early embryonic development. Compared diabetic rat ovary to healthy rat ovary in our study, it is seen that Gal-1 and Gal-3 expressions are different. It can suggest that these differences may be due to diabetes. Hinck et al. (2003) reported that type-I diabetes can lead to ovarian dysfunctions. A study conducted by Bitar (1997) was reported that anovulation and delayed sexual maturation in animals, as well as irregular estrous cycle, in the STZ-induced experimental diabetes model result from a decrease in the activity of the hypothalamic norepinephrine at proestrus stage. Chieri et al. (1969) and Colton et al. (2003) reported that diabetes lowers ovulation rate and also brings about embryonic growth retardation (Colton et al.). In present study, it has been reached a conclusion that high glucose concentration may affect Galectin-1 and -3 expression in streptozotocininduced diabetic rat ovary during follicular development. It was found that Gal-1 and -3 are intensively expressed in especially connective tissue of medulla region and blood vessels widely distributed within this connective and in the zona pellucida of oocytes in control and streptozotocintreated rat ovary. It was also established that they are very highly and strongly expressed in the antrum of tertiary follicles. In the present study, the fact that Gal- 1 and -3 are abundantly secreted by particularly tertiary follicles gives us the idea that these galectins may play a key role in oocyte development. Furthermore, it was determined that Galectin1 and 3 are differently expressed in diabetic rat ovary tissues. Generally speaking about ovary tissue, we were observed that intensity of Gal-3 staining is more than that of Gal-1 staining. It was noticed, however, that neither Gal-1 nor Gal3 is localized in primordial follicles of the experimental and control groups. The reason for lack of their immunohistochemical localization in these follicles may arise out of the insufficient activity of Gal-1 and Gal-3 at the early stages of development. This result is supported by the evidence that zona pellucida is not present in primordial follicles, and that Gal-1 and -3 are strongly expressed in zona pellucida during follicular development. In a comparative study carried out in 1994, cytological localization and cellular levels of TGFa have been investigated in ovarian tissue (Singh \& Armstrong, 1995). TGF- $\alpha$ and $-\beta$ are epidermal growth factor (EGF)-like polypeptides and stimulate the anchorage-independent growth of untransformed cells (Tekpetey et al., 1995). TGF$\alpha$ and $-\beta$ are transforming growth factors, which are known as the best local modulators of ovarian function. TGF- $\alpha$ bears a structural similarity to epidermal growth factor (EGF). Both of them also binds to the same receptor in a wide range of cells during proliferation and growth. Their receptors have been detected in ovarian cells. The study was reported that TGF- $\alpha$ expression increases by the development of the follicles and lutein cells also reach a maximum level during mid-luteal phase. In a study carried out by Vasir et al. (2000), TGF- $\alpha$ expression has been shown to be reduced in the diabetic group (Demir, 1995). When examined the immunostaining of TGF- $\alpha$ in addition to these findings, another study highlighted that this staining is more intense in developed and antral follicles and follicular-derived TGF$\alpha$ play an autocrine and/or paracrine role in modulating the follicular development (Tekpetey et al.). It has been put forward that its form in which TGF- $\alpha$ known as embryonic growth factor is found in the adult organism may be epidermal growth factor (EGF), which is likely to be involved in the proliferation and differentiation of granulosa cells in the ovary. It has been emphasized that TGF- $\alpha$ produced and released by the theca interna cells in the ovary enables phenotypic change to happen, which can be reversible, exists in the granulose and theca interna cells, and drives the resultant follicular activity (Perillo et al., 1997). Our study was observed that Galectin-1 and -3 expressions increase depending on follicular development and the expression is quite intense in the antrum portions of tertiary follicles. Therefore, we also thought that Galectin-1 and -3 may play a key role in modulating the follicular development. Our study has been shown that Galectin-3 is intensively localized in the epithelial, cytoplasm and connective tissue. Our study also indicates that Galectin 1 and -3 are expressed in the rat ovary in their own manner. As a matter of fact, the results of our study have revealed that expressions of Galectin 1 and 3 may alter in the rat ovary, their expression profiles differ, they react positively in many parts and they are mostly localized in cytoplasm, regardless of whether the rats are diabetic or non-diabetic. Formation of the theca cell layer occurs without the actions of LH. Because LH receptor is lacking in stromal cells to be differentiated into theca cells. After granulosa cells of follicle which it will surround become two or more layers, theca differentiation factors (TDFs) released from these cells stimulate mRNA expressions of LH receptors and steroidogenic enzymes (CYP11A, 3 $\beta$-HSD CYP17) required for androgen biosynthesis in theca precursor cells. The formation of theca cell layer in secondary follicle is an important physiological event for follicular development (Matur \& Solmaz, 2010). Reason why galectin- 1 is not expressed in the theca layer may be that Gal-1 does not recognize LH receptors and TDF to which it will bind. We suggest that reason for localization of Gal-3 in the theca layer may be due to the fact that Gal-3 does recognize LH receptors and TDF. When we look comparatively Gal- 1 and Gal-3 expressions in our study, we can say that expression intensity of Gal-1 in the zona pellucida is stronger than that of Gal-3. Zona pellucida consists of 3 protein complexes, called as ZP1, ZP2 and ZP3 
in human and mouse, which have been characterized by carbohydrate recognition domains (Green, 1997). To put it in different way, zona pellucida surrounding the oocyte is composed of 3 proteins, including ZPA, ZPB and ZPC. Our study has shown that intensity of Gal-1 staining is more than that of Gal-3 staining in zona pellucida of the secondary follicles, but that intensity of Gal-3 staining is more than that of Gal-1 staining in the tertiary follicles. This is because galectins are carbohydrate-binding proteins and carbohydrate-binding property of gal-1 may be due to higher than that of Gal-3. Absence of this situation in tertiary follicles may be, however, that as follicle grows carbohydrate-binding property of Gal-1 is declining. Our study indicates that Galectin-3 plays a role in follicular growth since Galectin-3 is more intensely localized in the cytoplasmic parts of growing follicles than in other ones. In brief, this study has demonstrated for the first time the relationship between Galectin-1 and Galectin-3 expressions and diabetes in the rat ovary. The results of this study seem to support that diabetes may alter immunolocalization of galectin- 1 and galectin- 3 proteins in the rat ovary tissue, and that these proteins are widely distributed in this tissue and play important roles in the rat ovarial function. Further studies are warranted to clarify the role of Galectin- 1 and -3 expressions in the diabetic and nondiabetic rat ovary. Consequently, this study has concluded that diabetes affects and increases the expressions of Galectin-1 and Galectin-3, that Gal-1 and -3 may play an essential role in the ovulation and follicular growth, that their localization is lacking in primordial follicles of the control and experimental groups since activity of Gal-1 and Gal-3 is too little in the early stages of development, and that also Galectin- 1 and -3 react positively in many regions of the ovary and are largely localized in the cytoplasm.

ÖZDENOGLU, B. \& SARAYDIN, S. U. ¿La diabetes altera la inmunolocalización de Galectina-1 y Galectina-3 en el ovario de rata? Int. J. Morphol., 34(2):742-751, 2016.

RESUMEN: La diabetes mellitus (DM) es una enfermedad metabólica debido a una deficiencia en la secreción de insulina por parte del páncreas o por una insuficiente respuesta de los tejidos a la insulina. El objetivo fue demostrar la inmunolocalización de las proteínas de unión beta-galactosa Galectina-1 y Galectina-3 en los ovarios de ratas diabéticas y su relación con la diabetes. Fueron utilizadas 50 ratas hembras maduras entre 8-10 semanas de edad, con un peso de 250-300 g. Con el fin de desarrollar DM en los animales, se inyectó a cada uno $60 \mathrm{mg} / \mathrm{kg}$ de estreptozotocina vía intravenosa. Después de la eutanasia, se realizó el procesamiento de rutina de los tejidos de las ratas diabéticas y no diabéticas para evaluar los tejidos ováricosa través de inmunohistoquímica. Se observaron expresiones fuertes de la Galectina-1 y Galectina-3 en el epitelio germinal y epitelio endotelial vascular del ovario. Si bien la fuerte e intensa expresión de Galectina-1 se observó en la zona pelúcida, la Galectina-3 tuvo una expresión más fuerte en las regiones de las células citoplasmáticas. La zona pelúcida tiene 3 complejos de proteínas (ZP1, ZP2 y ZP3) en ratas y en seres humanos y tienen la capacidad de reconocer los campos de carbohidratos en los tejidos. La fuerte expresión de las galectinas de esas regiones podría ser el resultado de las propiedades de unión a carbonhidratos expresión de Gal-3 en las regiones citoplasmáticas de los folículos en crecimiento, pudiendo sugerir que Gal-3 podría tener efectos sobre el crecimiento del folículo. En conclusión, las proteínas de unión beta-galactosa Gal-1 y Gal-3 tienen una mayor inmunolocalización en los ovarios de ratas diabéticas, en comparación a los controles. La diabetes podría incrementar las expresiones de Gal-1 y Gal-3 en el tejido ovárico.

PALABRAS CLAVE: Galectina-1; Galectina-3; Ovario; Diabetes; Ratas.

\section{REFERENCES}

Akkoyunlu, G.; Üstünel, I. \& Demir, R. Immunohistochemical distribution of transforming growth factor alpha, laminin, fibronectin and desmin in rat ovary. Turk. J. Biol., 24:467-81, 2000 .

Balla, A.; Danilovich, N.; Yang, Y. \& Sairam, M. R. Dynamics of ovarian development in the FORKO immature mouse: structural and functional implications for ovarian reserve. Biol. Reprod., 69(4):1281-93, 2003.

Bitar, M. S. The role of catecholamines in the etiology of infertility in diabetes mellitus. Life Sci., 61(1):65-73, 1997.

Chieri, R. A.; Pivetta, O. H. \& Foglia, V. G. Altered ovulation pattern in experimental diabetes. Fertil. Steril., 20(4):661-6, 1969.
Colton, S. A.; Humpherson, P. G.; Leese, H. J. \& Downs, S. M. Physiological changes in oocyte-cumulus cell complexes from diabetic mice that potentially influence meiotic regulation. Biol. Reprod., 69(3):761-70, 2003.

Demir, R. I'nsanın Gelisimi ve Implantasyon Biyolojisi. Ankara, Palme Yayınc1lık, 1995.

Diabetes mellitus. Report of a WHO Study Group. World Health Organ. Tech. Rep. Ser., 727:1-113, 1985.

Erickson, G. F. Normal ovarian function. Clin. Obstet. Gynecol., 21(1):31-52, 1978.

Eriksson, U. J.; Brolin, S. E. \& Naeser, P. Influence of sorbitol 
accumulation on growth and development of embryos cultured in elevated levels of glucose and fructose. Diabetes Res., 11(1):27-32, 1989.

Gong, H. C.; Honjo, Y.; Nangia-Makker, P.; Hogan, V.; Mazurak, N.; Bresalier, R. S. \& Raz, A. The NH2 terminus of galectin-3 governs cellular compartmentalization and functions in cancer cells. Cancer Res., 59(24):6239-45, 1999.

Green, D. P. Three-dimensional structure of the zona pellucida. Rev. Reprod., 2(3):147-56, 1997.

Hattori, M. \& Horiuchi, R. Biphasic effects of exogenous ganglioside GM3 on follicle-stimulating hormone-dependent expression of luteinizing hormone receptor in cultured granulosa cells. Mol. Cell. Endocrinol., 88(1-3):47-54, 1992.

Hinck, L.; Thissen, J. P. \& De Hertogh, R. Identification of caspase6 in rat blastocysts and its implication in the induction of apoptosis by high glucose. Biol. Reprod., 68(5):1808-12, 2003.

Kaltner, H.; Lips, K. S.; Reuter, G.; Lippert, S.; Sinowatz, F. \& Gabius, H. J. Quantitation and histochemical localization of galectin-1 and galectin-1-reactive glycoconjugates in fetal development of bovine organs. Histol. Histopathol., 12(4):94560, 1997.

Krzeslak, A. \& Lipinska, A. Galectin-3 as a multifunctional protein. Cell. Mol. Biol. Lett., 9(2):305-28, 2004.

Kurçer, Z. \& Karaoglu, D. The use of alloxan and streptozotocin in experimental diabetes models. Turk. J. Endocrinol. Metab., 16(2):34-40, 2012.

Kwak, D. H.; Jung, K. Y.; Lee, Y. C. \& Choo, Y. K. Expressional changes of ganglioside GM3 during ovarian maturation and early embryonic development in $\mathrm{db} / \mathrm{db}$ mice. Dev. Growth Differ., 45(1):95-102, 2003.

Matur, I. \& Solmaz, S. Ovarian follikül gelis,iminin moleküler temelleri. Arsiv, 19:193, 2010.

Nio-Kobayashi, J. \& Iwanaga, T. Differential cellular localization of galectin- 1 and galectin- 3 in the regressing corpus luteum of mice and their possible contribution to luteal cell elimination. J. Histochem. Cytochem., 58(8):741-9, 2010.

Perillo, N. L.; Uittenbogaart, C. H.; Nguyen, J. T. \& Baum, L. G. Galectin-1, an endogenous lectin produced by thymic epithelial cells, induces apoptosis of human thymocytes. J. Exp. Med., 185(10):1851-8, 1997.

Saglam, H. Diyabet ve Enfeksiyonlar - Derleme. J. Curr. Pediatr. 2:44-52, 2004.

Seyrek, K.; Özcan, A. \& Erbas, H. Histochemical study of expression of galectin-1 and its reactive carbohydrate epitopes in normal bovine embryonal and adult pancreas. Israel J. Vet. Med., 56(1):25-8, 2001.
Singh, B. \& Armstrong, D. T. Transforming growth factor alpha gene expression and peptide localization in porcine ovarian follicles. Biol. Reprod., 53(6):1429-35, 1995.

Tekpetey, F. R.; Singh, B.; Barbe, G. \& Armstrong, D. T. Localization of epidermal growth factor (EGF) receptor in the rat corpus luteum, and EGF and transforming growth factoralpha stimulation of luteal cell steroidogenesis in vitro. Mol. Cell. Endocrinol., 110(1-2):95-102, 1995.

Vaskivuo, T. E.; Ottander, U.; Oduwole, O.; Isomaa, V.; Vihko, P.; Olofsson, J. I. \& Tapanainen, J. S. Role of apoptosis, apoptosisrelated factors and 17beta-hydroxysteroid dehydrogenases in human corpus luteum regression. Mol. Cell. Endocrinol., 194(1-2):191-200, 2002.

Vasir, B.; Reitz, P.; Xu, G.; Sharma, A.; Bonner-Weir, S. \& Weir, G. C. Effects of diabetes and hypoxia on gene markers of angiogenesis (HGF, cMET, uPA and uPAR, TGF-alpha, TGFbeta, bFGF and Vimentin) in cultured and transplanted rat islets. Diabetologia, 43(6):763-72, 2000.

Volante, M.; Bozzalla-Cassione, F.; Orlandi, F. \& Papotti, M. Diagnostic role of galectin-3 in follicular thyroid tumors. Virchows Arch., 444(4):309-12, 2004.

\section{Correspondence to:}

Prof. Dr. Serpil Ünver Saraydin

Cumhuriyet University

Medicine Faculty

Histology-Embryology Department

58140 Sivas

TURKEY

Email: unversaraydin@gmail.com

Received: 10-08-2015

Accepted: 18-02-2016 